University of Nebraska - Lincoln

DigitalCommons@University of Nebraska - Lincoln

$2-2000$

\title{
Post-Mazama (7 KA) Faulting Beneath Upper Klamath Lake, Oregon
}

Steven M. Colman

Joseph G. Rosenbaum

Richard L. Reynolds

Andrei M. Sarna-Wojcicki

Follow this and additional works at: https://digitalcommons.unl.edu/usgsstaffpub

Part of the Earth Sciences Commons

Colman, Steven M.; Rosenbaum, Joseph G.; Reynolds, Richard L.; and Sarna-Wojcicki, Andrei M., "PostMazama (7 KA) Faulting Beneath Upper Klamath Lake, Oregon" (2000). USGS Staff -- Published Research. 287.

https://digitalcommons.unl.edu/usgsstaffpub/287

This Article is brought to you for free and open access by the US Geological Survey at DigitalCommons@University of Nebraska - Lincoln. It has been accepted for inclusion in USGS Staff -- Published Research by an authorized administrator of DigitalCommons@University of Nebraska - Lincoln. 


\title{
Short Notes \\ Post-Mazama (7 KA) Faulting Beneath Upper Klamath Lake, Oregon
}

\author{
by Steven M. Colman, Joseph G. Rosenbaum, Richard L. Reynolds, \\ and Andrei M. Sarna-Wojcicki
}

\begin{abstract}
High-resolution seismic-reflection profiles $(3.5 \mathrm{kHz})$ show that a distinctive, widespread reflection occurs in the sediments beneath Upper Klamath Lake, Oregon. Coring reveals that this reflection is formed by Mazama tephra (MT), about $7 \mathrm{ka}$ in age. The MT horizon is faulted in many places and locally displaced by as much as $3.1 \mathrm{~m}$. Differential displacement of multiple horizons indicates recurrent fault movement, perhaps three episodes since deposition of the Mazama. The pattern of faulting indicates northeast-southwest extension beneath the lake basin.
\end{abstract}

\section{Introduction}

In the evening of September 20, 1993, two earthquakes occurred about $20 \mathrm{~km}$ northwest of Klamath Falls, Oregon, and just west of Upper Klamath Lake. The two earthquakes, both with sizes of $M_{\mathrm{w}} 6.0$, were separated by a few hours and resulted in widespread damage and two deaths (Sherrod, 1993). Ground cracking and landslides were reported, but no surface-fault displacement related to the earthquakes was observed (Wiley et al., 1993). No late Holocene fault scarps have been described in the Klamath Lakes Valley. Historical seismicity in the area is low (Hawkins et al., 1989; Wiley et al., 1993).

Klamath Falls and Upper Klamath Lake lie within the westernmost basin of the Basin and Range Province, immediately east of Crater Lake and the Cascade Range. The basin is marked by numerous young fault scarps, some of which displace late Pleistocene deposits (Hawkins et al., 1989) or are fresh enough to suggest that they have been active within the last $10 \mathrm{ka}$ (Sherrod, 1993). On the west side of the Klamath Lake Valley, two fault zones, the Lake of the Woods fault zone and the West Klamath Lake fault zone (Fig. 1), appear to form an en-echelon western margin of the Klamath graben. Each zone consists of a complicated pattern of individual strands, which on a broad scale have a northerly trend. However, in the vicinity of Upper Klamath Lake, the faults have a more northwesterly trend (Wiley et al., 1993; Bacon et al., 1999). The Klamath graben is thought to extend into the Cascade Range, where its northern end is marked by Mount Mazama and the Crater Lake caldera (Bacon et al., 1999).

The 1993 earthquakes (Fig. 1) have focal mechanisms indicative of steeply northeast-dipping normal displacement and are thought to have occurred on the Lake of the Woods fault zone (Braunmiller et al., 1995; Dreger et al., 1995). The West Klamath Lake fault zone shows evidence of late Pleistocene to early Holocene faulting at the mouths of can- yons on the west side of the Klamath Lake valley, but the surfaces of late Holocene deposits in the valley proper are not displaced (Hawkins et al., 1989). The bend in the regional structural grain reflected in the northwesterly trend of the faults in the Upper Klamath Lake area may have contributed to the size and doublet nature of the 1993 earthquakes (Braunmiller et al., 1995).

In the course of studies aimed at obtaining paleoclimate records from Upper Klamath Lake, we surveyed the lake with high-resolution seismic-reflection equipment. The resulting data showed that sediments beneath the lake were displaced by faulting (Fig. 2). In this article, we discuss the pattern and age of that faulting.

\section{Seismic-Reflection Data and Stratigraphic Age}

We collected about $250 \mathrm{~km}$ of high-resolution seismicreflection data from Upper Klamath Lake, Oregon, along tracklines shown in Figure 1. The data were collected using a side-mounted array of four $3.5 \mathrm{kHz}$ transducers, two sending the signal and two receiving the returns. The data were located with military-grade GPS. Details of the data-collection methods are given in Nichols and Colman (1996).

In many areas of the lake (dashed lines in Fig. 1), a very strong, sharp reflection from the lake floor, along with its multiple-path echoes, were the only reflections received (right edge of Fig. 3a). Lack of penetration of the lake sediments was surprising because they consist of soft diatomaceous ooze. The seismic signature of this strong lakefloor reflection is not like that associated with biogenic gas in sediments, which is typically more diffuse and not strictly coincident with the lake floor. However, the blue-green algae Oscillatoria princeps, which grows as a mat on the lake floor, has been observed to collect gas, in some cases enough to raise sections of the lake floor $30 \mathrm{~cm}$ across to the surface 


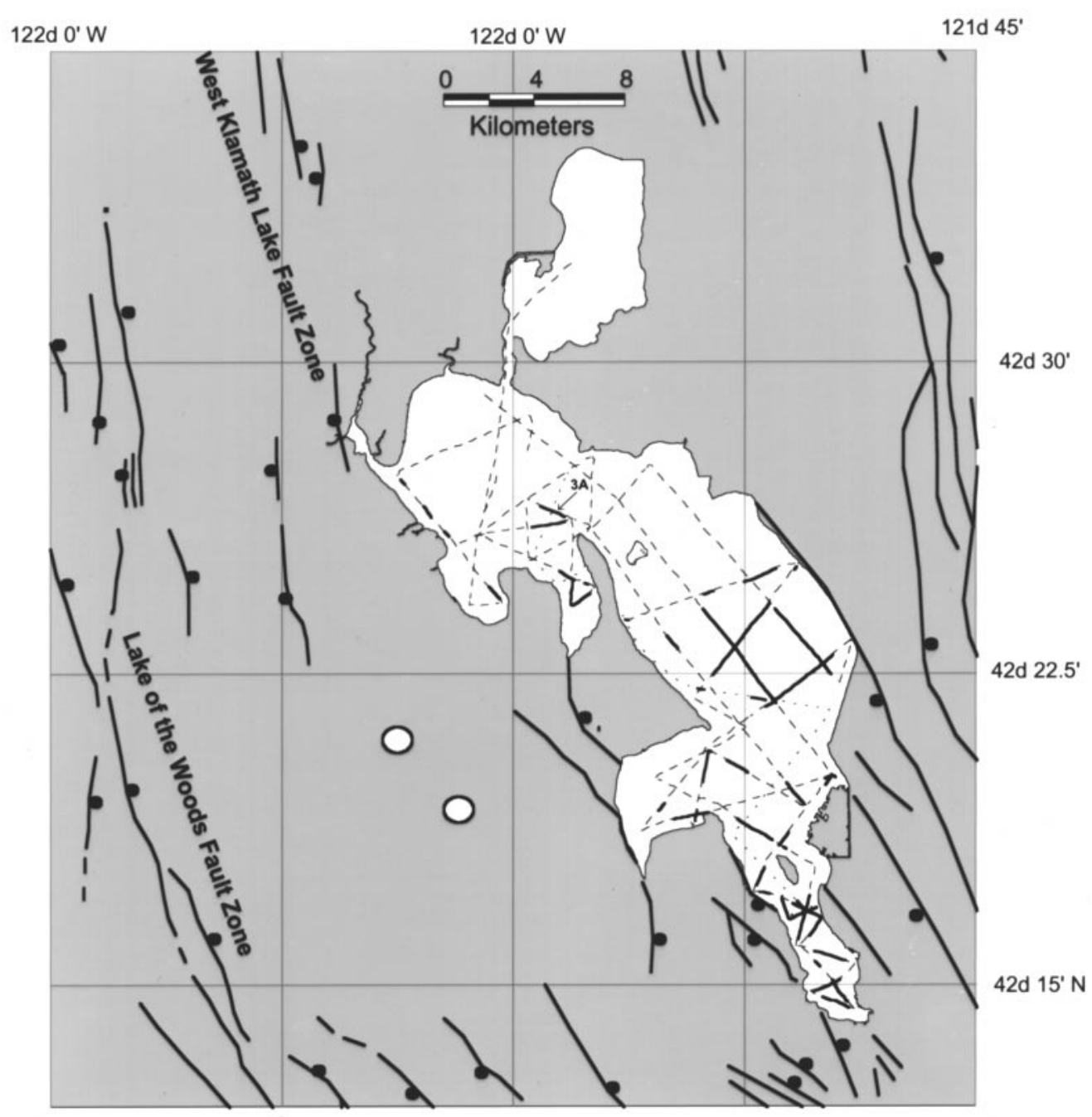

Figure 1. Map of Upper Klamath Lake area showing the lake and nearby tectonic features. Faults (ball on downtown side) and epicenters of 1993 earthquakes (open circles) are from Keefer and Shuster (1993) as modified from Wiley et al. (1993). Seismic-reflection tracklines in the lake are solid where significant penetration into sediments was achieved, dashed otherwise. 3A with arrow indicates the location of profile A in Figure 3.

(Sanville et al., 1974). Even a minor collection of gas in a lake-floor algal mat would create a large acoustic impedance contrast, and we infer that this is the reason for the strong lake-floor reflection. Differences in the distribution of the strong lake-floor reflection during two phases of our data collection (July and September, 1996) are also consistent with this mechanism.

Where the acoustic signals penetrated the sediments beneath Upper Klamath Lake, the lake-floor reflection was nearly imperceptible (left side of Fig. 3a), consistent with the watery, diatomaceous nature of the sediments. In most cases, the first discernable reflection was a very strong, distinctive reflection that occurred at least several meters below the lake floor. In some cases, faint reflections occurred higher in the section. A variety of reflections occur below the first prominent one, in most cases subparallel but in some cases truncated at an angular unconformity.

A 9-m core was obtained on line 17 (Fig. 3a) using a modified Livingstone corer (Wright, 1967). At this site, the water depth was $2.7 \mathrm{~m}$, and the distinctive, strong, first reflection occurred at about $10.0 \mathrm{~m}$ below the lake surface (Fig. 3a). At a depth of $6.9 \mathrm{~m}$ in the core $(9.6 \mathrm{~m}$ below the lake surface), we encountered a $3-\mathrm{cm}$-thick bed of ash and pumice clasts. On the basis of the chemical composition of the glass in this tephra unit (Table 1) determined by microprobe analysis (Sarna-Wojcicki et al., 1991), the unit is the Mazama tephra, which has an ${ }^{14} \mathrm{C}$ age of about $6.85 \mathrm{ka}$ (Bacon, 1983 ) or a more recent estimate of $6.73 \pm 0.04 \mathrm{ka}$ (Hallet et al., 1997). The latter translates to 7540 calendar years B.P. 


\section{$121 \mathrm{~d} 52.5^{\prime}$}

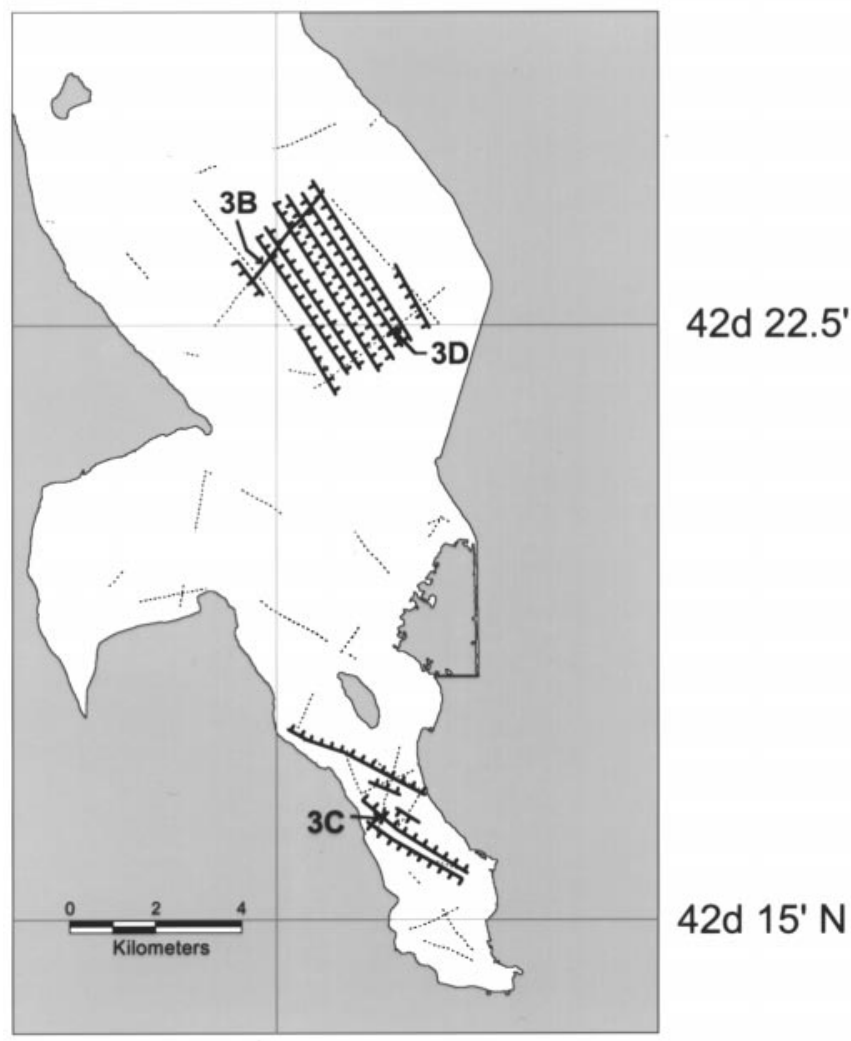

Figure 2. Map of the central and southern basins of Upper Klamath Lake, showing seismic reflection lines in which sublakefloor reflections were seen (light dashed lines), the location of profiles B-D in Figure 3 (solid lines), and faults observed in the seismic reflection data (hatchured lines, ticks on downdropped side).

( $2 \sigma$ range $7470-7620$ ), using the CALIB 3.0.3c program (Stuiver and Reimer, 1993)

\section{Neotectonic Implications}

The Mazama tephra horizon can be traced throughout much of the lake, and in many places, it is displaced by faulting (Fig. 3b-3d). The large number of faults and the shallow penetration of the seismic data make it difficult to determine how individual fault traces relate to primary faults at depth or mapped faults on shore. However, it is clear that the faults are oriented northwest, subparallel to nearby faults on shore (Figs. 1-2). Two well-defined, northwest-trending, graben structures occur, one in the south basin of the lake and one in the central basin (Fig. 2). These grabens are characterized by steep, symmetrically arrayed, normal faults that face the graben axes (Fig. 3b). This pattern is consistent with dominantly extensional stresses and with mostly normal movement indicated by earthquake focal mechanisms (Braunmiller et al., 1995).

The Mazama tephra horizon is displaced $1-2 \mathrm{~m}$ on most of the faults observed; the maximum displacement seen on a single fault is about $3.1 \mathrm{~m}$. In Figure $3 \mathrm{c}$, the horizon is displaced 3.0 and $0.6 \mathrm{~m}$ on two closely spaced fault traces. In most cases, the data do not provide evidence for more than one episode of faulting, but some of the faults show decreasing throw upward, indicating recurrent movement. The clearest example is a fault in the central basin of the lake (Fig. 3d; this fault also crosses line 29 in Fig. 3b). Three horizons in Figure 3d, the oldest of which is the Mazama tephra horizon, are displaced by $1.9,1.7$, and $1.1 \mathrm{~m}$, which suggests at least three episodes of displacement since deposition of the Mazama tephra. These displacements take into account warping immediately adjacent to the fault, but they may be affected by broader-scale warping. They do not take into account earthquake-induced differential compaction. The similarity in the patterns of faulting observed on different seismic lines suggests that differential compaction has been minor.

These data imply greater density of faults than has been documented on the flat floor of the basin surrounding the lake, which is underlain by late Holocene fluvial, marsh, and lacustrine sediments. None of the faults beneath the lake are expressed on the lake floor; they are observable only in highresolution seismic-reflection profiles, which are easier to collect in the lake than on land. No fault scarps cut the surface of late Holocene deposits either on the valley floor or beneath the lake, and none were produced in the 1993 earthquake (Wiley et al., 1993). The seismic-reflection data also indicate for the first time that multiple episodes of faulting have occurred since about $7 \mathrm{ka}$ and that the recurrence interval of major earthquakes in the area may be as little as a few thousand years. The maximum displacement of about 3 $\mathrm{m}$ since $7 \mathrm{ka}$ documented here (Fig. 3c) yields a slip rate of $0.43 \mathrm{~mm} / \mathrm{yr}$. This estimate is qualified by uncertainties in the displacement measurements, which were discussed previously. In addition, the time interval is subject to interpretation. We have not considered the time interval during which stress accumulated before the first post- 7 ka event; on the other hand, the time interval during which the movement actually took place may be less than 7,000 years.

The longer-term average slip rate on faults bounding the Klamath graben has been estimated in two ways. Displacements of dated lava flows on faults near Crater Lake indicate a long-term rate of $0.3 \mathrm{~mm} / \mathrm{yr}$ over the last $300 \mathrm{ka}$ (Bacon et al., 1999). An intermediate-term (130 ka) rate of displacement on the West Klamath Lake fault zone, based on scarps in late Pleistocene and early Holocene deposits was estimated to be $0.17 \mathrm{~mm} / \mathrm{yr}$ (Hawkins et al., 1989). Considering the fact that slip rates may vary considerably over shorter time intervals (cf. Wells and Coppersmith, 1994), our estimate of $0.43 \mathrm{~mm}$ is remarkably close to the long-term average of $0.3 \mathrm{~mm} / \mathrm{yr}$ (Bacon et al. 1999). It is also considerably larger than that implied by $1-2 \mathrm{~m}$ fault scarps in early Holocene alluvium in tributaries to the Klamath Lake valley (Hawkins et al., 1989) and by the absence of fault scarps on the late Holocene floor of the valley. 

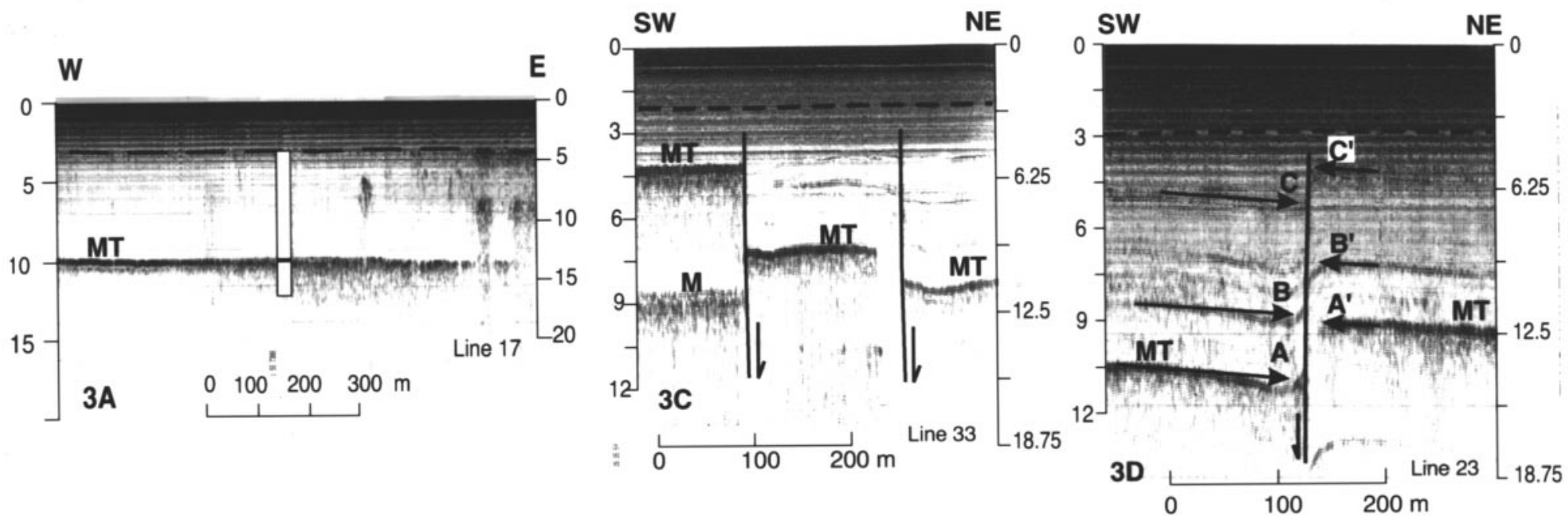

sw

NE

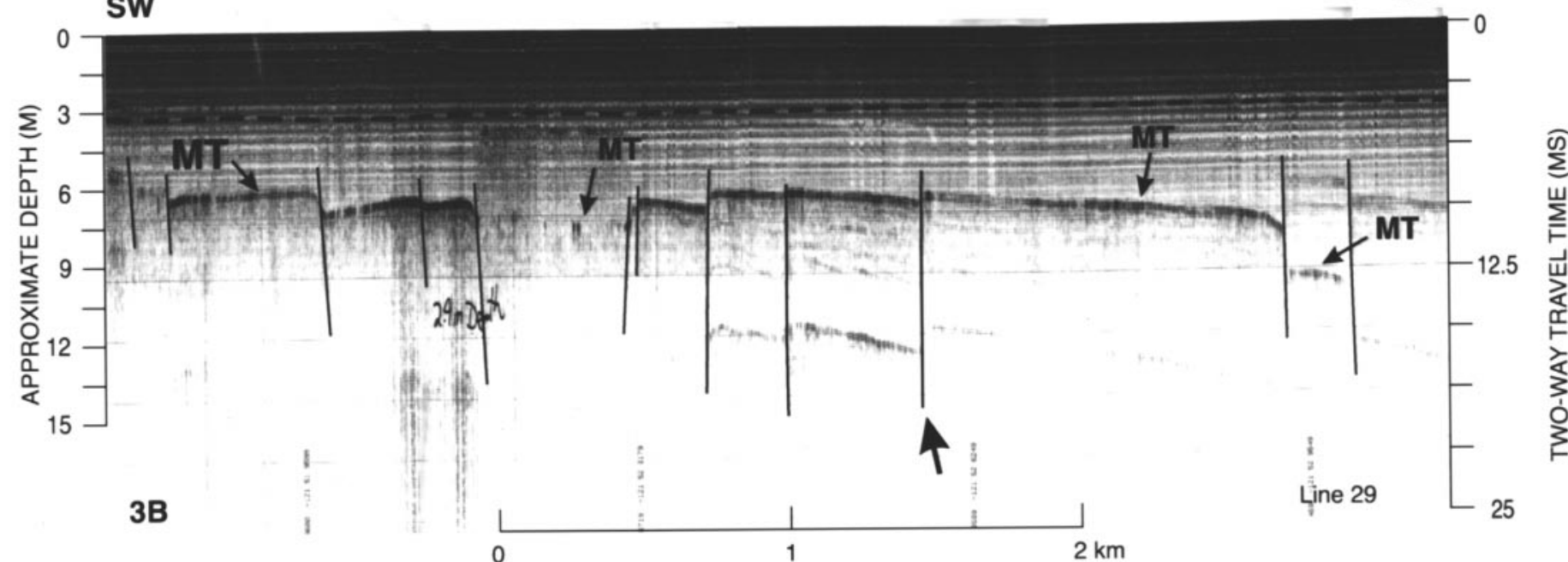

Figure 3. Seismic-reflection profiles ( $3.5 \mathrm{kHz}$ ) from Upper Klamath Lake. Locations shown in Figure 1 and 2. Dashed line near the top of each profile indicates lake floor. (a) Profile through core site, showing the position of the Mazama tephra (MT) in the core, exactly corresponding to a distinctive reflection. (b) Profile through central basin of the lake, approximately perpendicular to strike, showing numerous offsets of the Mazama tephra horizon (MT), symmetrically arrayed around a central graben. Heavy arrow indicates the fault shown in Fig. 3d on a different seismic line. (c) Profile showing near-maximum observed displacement (3.0) and smaller displacement $(0.6 \mathrm{~m})$ of the Mazama tephra (MT). M indicates multiple reflection. (d) Profile showing progressive offset of individual horizons, indicating recurrent fault movement. Displacements A-A' (Mazama tephra, MT), $1.9 \mathrm{~m}$; B-B', $1.7 \mathrm{~m}$; and C-C', $1.1 \mathrm{~m}$. 
Table 1

Results of Electron-Microprobe Analysis of Mazama Ash Bed Sample from Klamath Lake and Average Composition of Mazama Ash Bed.*

\begin{tabular}{|c|c|c|c|c|c|c|c|c|c|c|}
\hline Sample & $\mathrm{SiO}_{2}$ & $\mathrm{Al}_{2} \mathrm{O}_{3}$ & $\mathrm{Fe}_{2} \mathrm{O}_{3}$ & $\mathrm{MgO}$ & $\mathrm{MnO}$ & $\mathrm{CaO}$ & $\mathrm{TiO}_{2}$ & $\mathrm{Na}_{2} \mathrm{O}$ & $\mathrm{K}_{2} \mathrm{O}$ & Total $\dagger$ \\
\hline KL-D86 & 73.32 & 14.37 & 2.05 & 0.45 & 0.04 & 1.54 & 0.43 & 5.02 & 2.76 & 99.98 \\
\hline$\pm \sigma(13$ shards $)$ & 1.30 & 0.29 & 0.10 & 0.03 & 0.02 & 0.09 & 0.05 & 0.20 & 0.07 & \\
\hline Mazama Ash & 72.79 & 14.65 & 2.12 & 0.46 & 0.05 & 1.61 & 0.42 & 5.19 & 2.71 & 100.00 \\
\hline$\pm \sigma$ (100 samples. $)$ & 0.35 & 0.23 & 0.04 & 0.02 & 0.01 & 0.06 & 0.02 & 0.18 & 0.08 & \\
\hline
\end{tabular}

*Charles Meyer, USGS, Menlo Park, CA, analyst.

$\dagger$ Total recalculated to 100 percent, fluid-free basis.

\section{Conclusions}

Despite interest in seismotectonic hazards (Hawkins et al., 1989; Bacon et al., 1999) and the two $M_{\mathrm{w}} 6.0$ earthquakes that occurred near Klamath Falls in 1993 (Wiley et al., 1993), no faulting of deposits younger than 7 ka has been previously documented in the Upper Klamath Lake area. In contrast, new high-resolution seismic-reflection data from Upper Klamath Lake show clear evidence of $3 \mathrm{~m}$ or more of post-7 ka faulting in this western-most basin of the Basin and Range Province. The data suggest recurrent displacement of the Mazama tephra along northwesterly trending, graben-bounding faults beneath the lake. Although earthquake recurrence intervals and tectonic slip rates have significant uncertainties, our estimated slip rate of $0.43 \mathrm{~mm} / \mathrm{yr}$ for the last $7 \mathrm{ka}$ is quite close to the estimate of $0.3 \mathrm{~mm} / \mathrm{yr}$ for the last $300 \mathrm{ka}$ (Bacon et al., 1999). Recurrence intervals and slip rates appears to be significantly higher than suggested by preserved fault scarps.

\section{Acknowledgments}

We thank D. R. Nichols for help in collecting the seismic data and G. Skipp for help in collecting cores in Upper Klamath Lake. Helpful reviews of the paper were provided by W. P. Dillon, K. Haller, and R. N. Oldale, Our work on Upper Klamath Lake was supported by the Global Change and Climate History Program of the U.S. Geological Survey.

\section{References}

Bacon, C. R. (1983). Eruptive history of Mount Mazama and Crater Lake Caldera, Cascade Range, U.S.A., J. Volcanology Geotherm. Res. 18, 57-115.

Bacon, C. R., M. A. Lanphere, and D. E. Champion (1999). Late Quaternary slip rate and seismic hazards of the West Klamath Lake Fault zone near Crater Lake, Oregon Cascades, Geology 27, 43-46.

Braunmiller, J., J. Nabelek, B. Leitner, and A. Qamar (1995). The 1993 Klamath Falls, Oregon, earthquake sequence: source mechanisms from regional data, Geophys. Res. Lett. 22, 105-108.

Dreger, D., J. Ritsema, and M. Pasyanos (1995). Broadband analysis of the 21 September, 1993 Klamath Falls earthquake sequence, Geophys. Res. Let. 22, 997-1000.

Hallet, D. J., L. U. Hills, and J. J. Clague (1997). New accelerator mass spectrometer radiocarbon ages for the Mazama tephra layer from Kootenay National Park, British Columbia, Canada, Can. J. Earth Sci. 34, 1202-1209.

Hawkins, F. F., L. L. Foley, and R. C. LaForge (1989). Seismotectonic study for the Fish Lake and Fourmile Lake dams, Rogue River Pro- ject, Oregon, U.S. Bureau of Reclamation, Seismotectonic Report 893, $26 \mathrm{pp}$.

Keefer, D. K., and R. L. Schuster (1993). Landslides caused by the Klamath Falls, Oregon, earthquakes of September 20, 1993, Earthquakes and Volcanos 24, 140-146.

Nichols, D. R. and S. M. Colman (1996). High resolution acoustic survey techniques and coring operations, Upper Klamath Lake and Lake of the Woods, Oregon, U.S. Geological Survey Open File Report 96734, 8 pp.

Sanville, W. D., C. F. Powers, and A. R. Gahler (1974). Sediments and sediment-water nutrient interchange in Upper Klamath Lake, Oregon, U.S. Environmental Protection Agency Report EPA-660/3-74-015, $45 \mathrm{pp}$.

Sama-Wojcicki, A. M., K. R. Lajoie, C. E. Meyer, D. P. Adam, and H. J. Reick (1991). Tephrochronologic correlation of upper Neogene sediments along the Pacific margin, conterminous United States, in Quaternary Non-Glacial Geology: Conterminous United States, R. B. Morrison (Editor), Vol. K-2, Geological Society of America, Decade of North American Geology, Boulder, 117-140.

Sherrod, D. R. (1993). Historic and prehistoric earthquakes near Klamath Falls, Oregon, Earthquakes and Volcanoes 24, 106-120.

Stuiver, M. and P. J. Reimer (1993). Extended ${ }^{14} \mathrm{C}$ data base and revised CALIB $3.0{ }^{14} \mathrm{C}$ age calibration program, Radiocarbon 35, 215-230.

Wells, D. L. and K. J. Coppersmith (1994). New empirical relationships among magnitude, rupture length, rupture width, rupture area, and surface displacement, Bull. Seism. Soc. Am. 84, 974-1002.

Wiley, T. J., D. R. Sherrod, D. K. Keefer, A. Qamar, R. L. Shuster, J. W. Dewey, M. A. Mabey, G. L. Black, and R. E. Wells (1993). Klamath Falls earthquakes, September 20, 1993-including the strongest quake ever measured in Oregon, Oregon Geology 55, 127-134.

Wright, H. E. (1967). A square-rod piston sampler for lake sediments, $J$. Sedimentary Petrology 37, 975-976.

U.S. Geological Survey

384 Woods Hole Rd.

Woods Hole, MA 02543

scolman@usgs.gov

(S.M.C.)

U.S. Geological Survey

MS 980, Box 25046

Denver Federal Center

Denver, CO 80225

(J.G.R., R.L.R.)

U.S. Geological Survey

MS 975, 345 Middlefield Rd.

Menlo Park, CA 94025

(A.M.S.W.)

Manuscript received 24 March 1999. 